\title{
Investigation of Musculoskeletal Disorders Among Mid-old Aged Woman Caregiver at a Long-term Hospital
}

\author{
Young-Youl You ${ }^{1}$, Byoung-Hee Lee ${ }^{2}$ \\ ${ }^{1}$ Department of Rehabilitation, Graduate School of Health Sciences, Hallym University, Chuncheon, 200-702 \\ ${ }^{2}$ Department of Physical Therapy, Sahmyook University, Seoul, 139-742
}

\begin{abstract}
Objective: The purpose of this study was to analyze the risk factors of the musculoskeletal workload of mid-old-age female caregivers by identifying work postures and subjective symptoms. Method: This study was carried out on a total of 206 subjects 206 mid-old-age caregivers(45 65 years old) from November 2009 to April 2010: 206 mid-old-age caregivers (45 65 years old) at the long-term hospital. A questionnaires survey on general factors and subjective symptoms of subjects was conducted. The risk factors of the musculoskeletal workload evaluation method is based on OWAS, RULA, REBA according to occupation properties. Results: The analysis of the rates of the subjective symptoms showed that $78.6 \%$ subjects experience low back pain. The analysis of the work type showed that transfer is the highest rate(36.3\%) and position change is the second(18.2\%). The analysis of the work postures showed that the thrusted back with twisting position over $20^{\circ}$ is highest rate(37.4\%), the bended back forward with twisting position is the second(27.5\%). Conclusion: This study suggested that the need of preventive education for caregivers and workload improve. It is hoped that subsequent study on the difference of subjective symptoms between educated caregivers and non educated caregivers will be conducted.
\end{abstract}

Keywords: Musculoskeletal disorders, Mid-old-age workers, Female caregiver

\section{1. 서 론}

\section{1 연구의 배경 및 필요성}

현대의학의 발전으로 인간의 평균수명이 연장되고 있으나 서구식 식생활 및 생활환경 등의 변화로 인하여 뇌졸중의 발생빈도는 증가하고 있다(통계청, 2007). 대부분 뇌졸중 이후의 생존자들은 어느 정도의 신경학적 회복은 있지만, 약 30 60\%의 환자는 일상생활을 수행하는데 있어서 타인의 도움을 필요로 한다(Hopkins, H.L, Smith H.D, et al., 1993). 1999 년 15 개에 불과하던 노인병원이 2001년 32개, 2003 년 68 개, 2005년에는 193 개로 200개 가까이 급증했고, 2006년 7월말 290개로 증가했으며(대한병원협회, 2006), 환자 가족 역시 신체적 기능 손상과 인지장애 문제로 의존적
인 뇌졸중 환자를 장기간 간호해야 하기 때문에 신체적 불편 함을 갖게 된다(이강이와 송경애, 1996).

이렇듯 주로 뇌졸중 환자 및 신체적 활동에 대한 타인의 도움을 많이 받아야 하는 환자분들이 주로 입원해 있는 요 양병원에는 다양한 직종의 근로자들이 각기 다른 업무에 종 사하고 있다. 여기에는 직접 환자를 돌보는 의사, 간호사 등 을 비롯하여 환자의 진단과 처치 및 치료의 기술적인 지원을 담당하는 각종 기능직, 병원의 유지와 관리를 위해 행정 및 보조적인 서비스를 제공하는 직종 등이 포함된다(박정근 등, 2008). 이중 환자의 이동 운반에 대한 근골격계질환에 가장 많이 노출되어 있는 업무 종사군은 환자의 이동에 대한 빈도 로 보았을 때, 거동이 자유롭지 못한 환자를 들고(lifting), 이동하고, 운반하는 등의 인력운반작업에 많이 관여하는 간 병인과 간호사의 비율이 가장 높다고 할 수 있다. 
인력운반작업 (manual handling operation)은 운반물을 손이나 인체의 힘에 의해 들어 올리거나 내려 놓거나 밀거나, 당겨서 옮겨 놓는 작업을 의미하며, 정지 자세에서의 운반 물 운반과 지지 등을 모두 포함하는 개념이다(대한산업안전 협회, 2005). 이러한 작업으로 인한 육체적인 피로는 신체 적 감각 체계들의 작용을 저하시켜 결과적으로 신체의 작업 자세의 균형능력 저하로 이어진다(박재규, 박성하, 2004).

근골격계질환(musculoskeletal disorders, MSD)이란 "반복적인 동작, 부적절한 작업 자세, 무리한 힘의 사용, 날 카로운 면과의 신체접촉, 진동 및 온도 등의 요인에 의하여 발생하는 건강장해로서 목, 어깨, 허리, 상 - 하지의 신경 · 근육 및 그 주변 신체조직 등에 나타나는 질환"을 말한다 (노동부, 2003). 우리나라 전체 취업자의 연령대별 추이를 보면 고령화 현상에 따라 50세 이상의 근로자가 계속 증가 하고 있으며 (국가통계포탈, 2003 2008), 이에 따라 전체 근골격계질환자 수에서도 50세 이상의 근로자가 차지하는 점유율이 2000 년에는 전체 근골격계질환자의 $13.5 \%$ 에서 2007 년에는 $23.6 \%$ 로 증가하였으며 (한국산업안전보건공단, 산업재해현황통계 전산 자료, 2000 2007), 신체 부위별 자 각증상 호소율에 대한 조사 결과를 살펴보면 어깨, 허리, 목, 하지, 상지 등의 순으로 나타남으로써 환자 옮기기, 각종 집기류 취급 및 부서(팀)별 업무를 수행함에 있어 어깨 및 허리 부위의 통증을 많이 호소하고 있는 것으로 조사되었다 (Bejia et al., 2005).

간호 및 간병의 업무는 대부분 장기간 서있기, 환자를 향 해 상체 구부리기, 물건을 들어 올리거나 옮기기, 환자의 체 위를 변경시키거나 이동시키기, 침상정리하기 등으로 업무상 부적절한 자세와 과도한 힘을 사용할 수 밖에 없는 근골격계 질환의 위험요인이 높은 직업군에 속한다(오재민, 1997).

간병인이라하면 비 의료인으로서 환자의 보호자 역할을 하면서 환자를 돕고 보수를 받는 사람을 가리킨다(김기정, 1998). 의료기관 및 사회복지시설 등에서 근무하고 있는 간 병인의 평균 연령대 분석에서는 다른 직종군과는 달리 50 59 세가 가장 높게 나타나 있는 것으로 확인되었다(박현진 등, 2008). 현재 우리나라에서는 1980년대 이후부터 간병 인이 본격적으로 활동하였는데 이미 상당수에 이르고 있다. 현재 활동하고 있는 간병인력에 대해 전국 규모의 공식적이 고 체계적인 통계보고는 아직 없지만, 황나미 등(2006)의 연구에서 2005년 12월 말 기준으로 간병인수는 총 3만명으 로 추정된다고 하였으며, 최근 보건복지부에서 발표한 상반 기 보건복지분야 일자리 창출브리핑(2010)에서는 이전보다 만 오천명 정도가 증가를 하였다고 발표하였다. 하지만 비공 식적으로 간병노동을 제공하는 간병노동자 등을 고려하면 이보다 훨씬 큰 규모의 간병인력이 존재하고 있음을 예측할 수 있다.
간호사의 경우 평생 동안 요통 유병율이 35 90\%에 이 르며(Knibbe and Friele, 1996), 어깨 부위 근골격계질환 유병율은 43 53\%, 목 부위 유병율은 31 48\% 수준인 것 으로 조사되었다(Ando et al., 2000). 하지만 시대적 요구에 따라 늘어나고 있는 간병인들의 근골격계질환 유병율 혹은 발병율에 대한 내용은 다른 직종들에 비하여 조사가 없는 실정이다. 따라서 본 연구에서는 요양병원 중고령 여성 간 병인의 근골격계 부담작업, 실태 및 원인을 분석 평가한 후 이를 기초로 하여 간병인의 근골격계질환의 실태를 조사하 고 예방을 위한 기초 자료를 제시하는데 그 목적이 있다.

\section{2. 연구 방법}

\section{1 연구대상 및 기간}

본 연구는 중고령 간병인의 비율이 높은 경기도 소재 R 병원의 3 개 분원에 종사중인 간병인 총 327 명을 대상으로 산업안전공단(2004)의 근골격계질환 증상조사표를 기초로 설문을 실시하여 설문에 응답한 309명 (92\%) 중 45 65세 사이의 중고령에 해당하는 여성 간병인 206명을 연구대상 으로 하였다.

연구기간은 2009년 11월부터 2010년 3월까지로 설문 조사와 작업자세 분석을 통해 근골격계 자각증상과 위험요 인을 조사하였다. 설문조사는 2009년 11월 2일부터 11월 27일까지 설문응답 방법으로 시행하였다.

\subsection{1 작업자 특성 조사}

작업자의 일반적 특성으로는 작업자의 소속 부서명, 직종, 성별, 나이, 근무 년수, 현재 직종에서의 작업 경력, 주관적 인 육체 노동강도 등에 대하여 조사하였다.

\subsection{2 근골격계 자각증상 조사}

근골격계질환 및 증상 설문조사표는 표준화된 미국산업안 전보건연구원 (National Institute for Occupational Safety and Health, 이하 NIOSH, 1993)에서 정하는 작업관련 근 골격계질환의 증상 및 위험요인 평가지침의 표로 분류된 내 용을 참고하여 일반적 특성에 따른 근골격계 자각증상 호소 율을 분석하였다. NIOSH 기준에 따라 작업관련 근골격계질 환의 자각증상으로는 통증, 쑤심, 뻣뻣함, 저림, 감각마비, 화 끈거림이 적어도 일주일 이상 지속되고, 지난 1 년간 1 달에 1 번 이상 증상이 발생하며, 증상의 정도는 '중간 정도'를 호 소하는 경우를 적용하였다. 증상의 발생은 현재의 작업과 관 련하여 일어나야 하며 동시에 해당 부위의 사고나 급성 외상 이 없어야 한다. 이러한 기준에 따라 목, 어깨, 손/손목/손가 
락, 팔/팔꿈치, 허리, 다리/발 부위에 대해 증상의 빈도, 지 속시간, 통증강도 등을 묻는 항목으로 설문지를 구성하였다 (NIOSH 1993). 자각증상 기준을 만족하는 사람 중 증상을 호소하는 부위가 과거에 질환을 않은 적이 있거나, 현재의 작업과 무관한 교통사고 등으로 부상을 입은 경우는 제외하 였다.

\section{2 작업측정}

간병인들이 공통적으로 반복하고 있는 대표적인 업무를 분석해 본 결과, 침상교체, 대변 치우기, 병실청소, 목욕시키 기, 옷 갈아 입히기, 식사, 체위변경, 환자 옮기기 등 8가지 대표적인 작업유형으로 선별하였다. 각각의 작업에 대하여 작업의 전 내용을 현장에서 캠코더를 이용하여 실시간으로 촬영한 후 30 초 간격으로 등 간격 샘플링을 실시하였고, 작 업위험 평가 방법으로는 작업의 특성에 따라 OWAS, RULA, $\mathrm{REBA}$ 를 이용하여 분석하였다.

\section{3 측정 도구}

\subsubsection{OWAS(Ovako Working-posture Analysis Sys- tem)에 의한 자세 분석}

OWAS는 철강회사인 필란드의 Ovakooy에 의해 1970년 대 중반에 개발된 후에 Ovakooy와 Finish Institute for Occupational Health가 공동으로 수정하여 개발한 대표적인 작업 자세 평가기법이다(Scott and Lambe, 1996). OWAS 는 작업자들의 부적절한 작업 자세를 정의하고 평가하기 위 해 개발한 방법으로 작업자의 자세를 일정간격으로 관찰하여 분석하는 작업 샘플링 (Work sampling) 에 기본을 두고 있다.

\subsubsection{RULA(Rapid Upper Limb Assessment) tool에 의한 작업자세 분석}

RULA (McAtamney and Corlett, 1993) 점수는 어깨, 팔목, 손목, 목 등 상지에 초점을 맞추어 작업 자세로 인한 작업부하를 쉽고 빠르게 평가하기 위해 만들어진 기법으로 근육의 피로에 영향을 주는 인자들인 작업 자세나 정적 혹 은 반복적인 작업 여부, 작업을 수행하는데 필요한 힘의 크 기 등 작업으로 인한 근육부하의 평가이며 점수는 1 7점 사이에 분포하며, 이를 4 단계 위험도로 표시한다. 조치단계 1은 최종점수 1 2점, 조치단계 2는 최종점수 3 4점, 조치 단계 3은 최종점수 5 6점, 조치단계 4는 최종점수 7점 이 상이다. 수준 1 은 작업이 지속적, 반복적이지 않다면 작업 자세에 별 문제가 없다, 수준 2 는 작업 자세에 대한 추가 적인 연구가 필요하며, 바꾸는 것이 좋다. 수준 3 은 작업 자 세를 되도록 빨리 바꾸는 것이 좋다. 수준 4 는 작업 자세를
즉각 바꾸어야 하는 단계를 의미한다.

\subsubsection{REBA(Rapid Entire Body Assessment) tool에 의한 작업자세 분석}

REBA (Hignett, S. and McAtamney, L. 2000) 점수는 몸통과 고개의 각도 및 꼬이는지 여부, 다리는 양다리 또는 한쪽 다리만 사용하여 체중을 지탱하는지 여부, 무릎이 구 부려지는 정도, 위팔과 팔꿈치가 굽혀지는 정도, 손목은 틀 어지는지 또는 집기나 잡기 동작이 어떠한지에 따라 계산 하고 점수는 1 15점 사이에 분포하며, 이를 5 단계 위험도 로 표시한다. 수준 0 은 최종점수 1 점이며 위험도가 무시할 (Negligible) 단계이고, 수준 1은 최종점수 2 3점이며 낮은 (Low) 작업, 수준 2는 최종점수 4 7점으로 중간(Medium) 작업을 나타내고 수준 3은 최종점수 8 10점으로 높은 (High) 작업, 수준 4는 최종점수 11 15점으로 매우 높은 (Very high) 작업을 나타내며 바로 인간공학적 개선이 필요 한 단계를 의미한다.

\section{3. 연구결과}

\section{1 연구대상자의 일반적 특성}

\subsection{1 연령과 근무 년수}

설문에 응답한 중고령 여성 간병인의 평균나이는 55.7 세이며 그 중 40 대가 $27 \%, 50$ 대가 $48 \%, 60$ 대가 $25 \%$ 를 차지하는 것으로 나타났다. 근무 년수는 평균 2.44 년이다 (Table 1).

Table 1. General characteristics

\begin{tabular}{c|c|c|c}
\hline & Classification & Number of responses & Rate(\%) \\
\hline \multirow{4}{*}{ Age } & $45 \sim 49$ & 55 & 27 \\
\cline { 2 - 4 } & $50 \sim 59$ & 99 & 48 \\
\cline { 2 - 4 } & $60 \sim 65$ & 52 & 25 \\
\hline \multirow{4}{*}{$\begin{array}{c}\text { Job } \\
\text { tenure }\end{array}$} & $<1$ & 28 & 14 \\
\cline { 2 - 4 } & $1 \sim 2$ & 28 & 14 \\
\cline { 2 - 4 } & $2 \sim 3$ & 52 & 25 \\
\cline { 2 - 4 } & $3 \sim 4$ & 58 & 28 \\
\hline
\end{tabular}

\subsection{2 작업에 대한 육체적 불편도}

현재 수행중인 작업에 대한 육체적 불편도 조사에서는 '매우힘들다' $13.6 \%$, '힘든편이다' $54.4 \%$, '보통이다' $27.2 \%$, 
'힘들지 않다' $4.8 \%$ 로 조사되어 표 2와 같으며 그 중 $68 \%$ 가 힘든 것으로 응답하였다(Table 2).

Table 2. Physical discomfort for the job

\begin{tabular}{c|c|c|c|c}
\hline & Very hard & Hard & Usually & Not hard \\
\hline $\begin{array}{c}\text { Number of } \\
\text { responses }\end{array}$ & 28 & 112 & 56 & 20 \\
\hline Rate(\%) & 13.6 & 54.4 & 27.2 & 4.8 \\
\hline
\end{tabular}

\subsection{3 통증 부위}

작업자들의 근골격계 통증 유무에 대한 조사에서 허리에 통증을 호소하는 사람이 $78.6 \%$ 로 가장 높게 나타났으며 그 다음으로는 어깨 $54.3 \%$, 손/손목/손가락 $41.7 \%$, 팔/팔꿈치 $25.2 \%$, 다리/발 $11.6 \%$, 목 $8.7 \%$ 순으로 통증을 호소하는 것으로 나타났다(Table 3 ).

Table 3. Characteristics of musculoskeletal disorders of workers

\begin{tabular}{c|c|c}
\hline Site of pain & Number of appeals pain & Rate(\%) \\
\hline Neck & 18 & 8.7 \\
\hline Shoulder & 112 & 54.3 \\
\hline Arm/Elbow & 52 & 25.2 \\
\hline Hand/Wrist/Finger & 99 & 41.7 \\
\hline back & 162 & 78.6 \\
\hline Leg/Foot & 24 & 11.6 \\
\hline
\end{tabular}

\section{2 작업자세 분석 결과}

206명의 중고령 여성 간병인 중 샘플링 후 공통적으로 반 복하고 있는 대표적인 업무로 작업유형별 작업내용을 촬영하 여 30초 간격 샘플링한 내용으로 작업 자세를 평가하였다.

OWAS에 의한 작업 분석을 통해 작업 중 작업자가 취한

Table 4. The distribution of head / neck position

\begin{tabular}{c|c|c|c}
\hline Items & Code & Position description & Rate(\%) \\
\hline & 1 & Straight/Free & 34.6 \\
\cline { 2 - 4 } & 2 & $\begin{array}{c}\text { Bent forward 20 degrees or } \\
\text { more positions }\end{array}$ & 52.4 \\
\cline { 2 - 4 } Head & 3 & $\begin{array}{c}\text { More than 20 degrees bent } \\
\text { nideways stance }\end{array}$ & 6 \\
\cline { 2 - 4 } & 4 & $\begin{array}{c}\text { Bent back 20 degrees or } \\
\text { morepositions }\end{array}$ & 1.3 \\
\cline { 2 - 4 } & 5 & Torsion positions & 5.7 \\
\hline
\end{tabular}

자세를 각 신체 부위별로 누적 비율을 조사한 내용은 다음과 같았다(Table 4) (Table 5) (Table 6) (Table 7).

Table 5. The distribution of trunk / back position

\begin{tabular}{|c|c|c|c|}
\hline Items & Code & Position description & Rate(\%) \\
\hline \multirow{4}{*}{ Back } & 1 & Uprighting & 12.5 \\
\hline & 2 & $\begin{array}{l}\text { Bended Upper body } \\
\text { forward over } 20^{\circ}\end{array}$ & 22.6 \\
\hline & 3 & $\begin{array}{l}\text { thrusted back with twisting } \\
\text { position over } 20^{\circ}\end{array}$ & 37.4 \\
\hline & 4 & $\begin{array}{l}\text { bended back forward } \\
\text { with twisting }\end{array}$ & 27.5 \\
\hline
\end{tabular}

Table 6. The distribution of arm position

\begin{tabular}{c|c|c|c}
\hline Items & Code & Position description & Rate(\%) \\
\hline \multirow{4}{*}{ Arm } & 1 & $\begin{array}{c}\text { Shoulder with both } \\
\text { hands downward }\end{array}$ & 60.2 \\
\cline { 2 - 4 } & 2 & One hand raised over shoulder & 6 \\
\cline { 2 - 4 } & 3 & Hands raised over shoulder & 33.8 \\
\hline
\end{tabular}

Table 7. The distribution of leg position

\begin{tabular}{c|c|c|c}
\hline Items & Code & Position description & Rate(\%) \\
\hline \multirow{7}{*}{ Leg } & 1 & Sitting position & 22.1 \\
\cline { 2 - 4 } & 2 & Standing tall with leg & 37.6 \\
\cline { 2 - 4 } & 3 & Standing on one leg & 6 \\
\cline { 2 - 4 } & 4 & Standing on two legs bent & 25.7 \\
\cline { 2 - 4 } & 5 & Standing on one leg bent & 3.8 \\
\cline { 2 - 4 } & 6 & Kneeling position & 1 \\
\cline { 2 - 4 } & 7 & Walking & 3.8 \\
\hline
\end{tabular}

\section{3 작업내용 분석 결과}

간병인들이 공통적으로 반복하고 있는 대표적인 업무를 전수조사하여 직접관찰과 설문조사 등을 통해 분석해 본 결 과 병실, 치료실 등에서 환자 옮기기가 $36.3 \%$ 가장 많았으 며 침상에서 시간마다 이루어지는 욕창 방지를 위한 체위변 경이 $18.2 \%$ 로 두 번째 많은 비율을 차지하였다. 그 다음으 로는 식사시키기 $10.9 \%$, 옷 갈아 입히기 $9.1 \%$, 목욕시키기 $7.3 \%$, 병실청소 $7.2 \%$, 침상교체와 대변 치우기가 $5.5 \%$ 순 으로 나타났다(Table 8).

중고령 여성 간병인을 대상으로 근무 중 수행되는 대표적 인 작업에 대한 체크리스트 분석 결과는 Table 9 와 같았으 며 유해요인 분석 결과 노동부 고시(2003-24호) 11개 부 
담작업에 해당하는 작업은 병실과 치료실에서 이루어지는 환자 옮기기와 매 시간마다 주기적으로 이루어지는 체위변 경이 노동부 고시 11 개 부담작업 제 8호(하루에 10회 이상 $25 \mathrm{~kg}$ 이상의 물체를 드는 작업)에 해당하였으며 이 작업들 은 전체 작업 중 각각 $36.3 \%, 18.2 \%$ 를 차지하는 작업들 이었다.

Table 8. Work analysis questionnaire

\begin{tabular}{c|c}
\hline Work contents & Rate(\%) \\
\hline Bed replacement & 5.5 \\
\hline Clean up feces & 5.5 \\
\hline Clean ward & 7.2 \\
\hline To bath & 7.3 \\
\hline Change one's clothes & 9.1 \\
\hline To eat & 10.9 \\
\hline Position change & 18.2 \\
\hline Transfer & 36.3 \\
\hline
\end{tabular}

Table 9. Results of risk factors for Musculoskeletal work

\begin{tabular}{c|c|c|c|c}
\hline \multirow{2}{*}{ Work contents } & \multicolumn{4}{|c}{ Checklist } \\
\cline { 2 - 5 } & RULA & Risk & REBA & Risk \\
\hline Transfer & 7 & 4 & 13 & 4 \\
\hline Bed replacement & 4 & 2 & 6 & 2 \\
\hline To eat & 3 & 2 & 4 & 2 \\
\hline To bath & 4 & 2 & 7 & 2 \\
\hline Position change & 6 & 3 & 9 & 3 \\
\hline Clean up feces & 4 & 2 & 7 & 2 \\
\hline Change one's clothes & 5 & 3 & 8 & 3 \\
\hline Clean ward & 2 & 1 & 4 & 2 \\
\hline
\end{tabular}

환자 옮기기는 병실침대에서 또는 치료실 평상에서 휠체 어로 환자를 들어 이동하는 작업으로 노인병원의 특성상 간 병인 혼자서 이루어 지는 작업이 대부분이다. Figure 1은 대 부분의 간병인이 이용하는 방법으로 허리를 숙여(20 60도) 팔을 뻗은 상태에서 환자의 신체 부위를 잡고 옮기는 동작이 다. 휠체어와 병실침대, 치료실 평상의 높이가 모두 각각 다 르기 때문에 부적절한 자세의 범위가 커지고 환자의식의 유, 무 및 환자의 체중, 기타 환자의 상태에 따라 간병인 개개인 의 부담 차이가 발생한다.

체위변경은 의식이 없는 환자의 욕창 방지를 위해 일 정 시간마다 주기적으로 이루어 지는 반복적인 동작이며, 거동이 불편한 환자의 요구에 따라 간병인이 수시로 행하 여야 하는 동작이다. 침상의 폭과 침대의 높이가 조절이
불가능 하므로 Figure 2와 같이 허리를 숙인 상태에서 팔 을 이용 환자의 체위를 변경하는 동작이다.

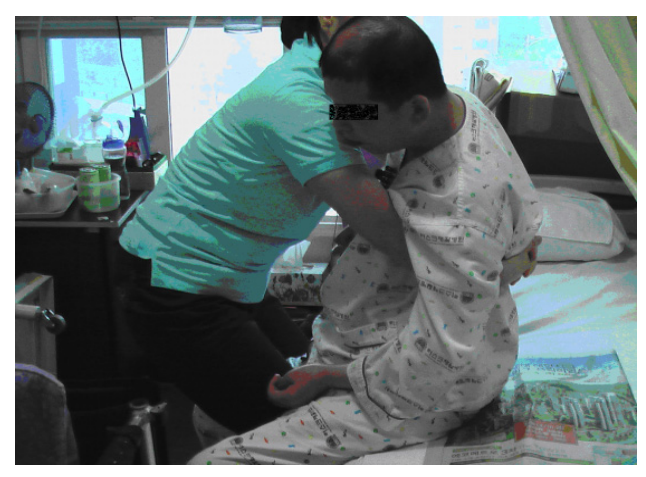

Figure 1. Patient transfer

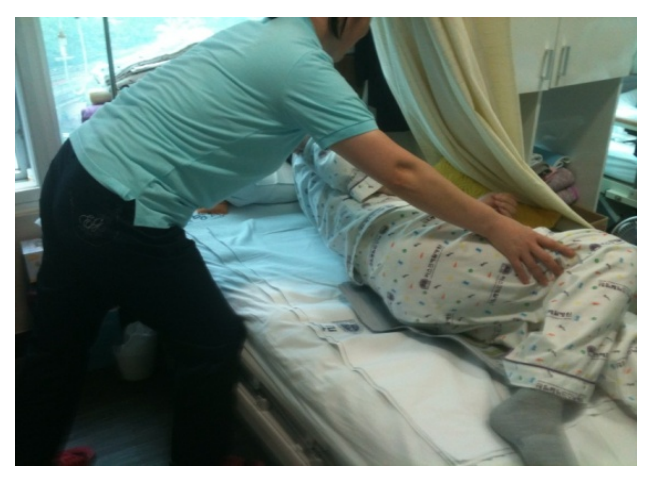

Figure 2. Change of position

\section{4. 결론 및 고찰}

우리나라의 비 제조업종에 근무하는 근로자수는 점점 증 가하고 있는 추세이며 이에 따라 재해자 또한 점점 증가하 고 있다. 대표적인 비 제조업종인 보건 및 사회복지사업에 서 발생하는 재해 중 대부분은 병원과 의원에서 발생되고 있다(박현진 등, 2008). 근골격계질환은 장기간에 걸쳐 반복 적으로 신체에 부담을 주는 작업에 종사하는 작업자들에게 유발될 가능성이 크다고 볼 수 있다. 또한 고령근로자들은 오랜 시간에 걸쳐 누적된 신체부담과 신체조직의 노화 현상 으로 인하여 젊은 연령층의 근로자에 비하여 근골격계질환 발생 위험성이 더욱 증가할 것이다(박기혁, 정병용, 2009). 간병인의 경우에는 환자이송 및 체위변경, 중량물 취급 등으 로 인한 사고성 요통 재해가 가장 많으며, 또한 대부분이 여성근로자 및 50 대의 비교적 고령근로자의 분포가 높게 나 
타나기 때문에, 전도, 충돌, 사고성 요통 등의 재해가 다발한 다고 박현진 등(2008)이 보고하였다.

본 연구에서는 요양병원에 근무중인 중고령 여성 간병인 을 대상으로 그들이 담당하는 업무에 대한 근골격계질환 유 해요인을 조사 분석하기 위해 실시하였다. 그 결과 노동부 고시 11 개 부담작업 중 제 8 호에 해당하는 2 개의 작업이 존 재하였으며 또한 위 두 작업 이외에도 11 개 부담작업과 유 사한 특성을 가진 작업이 많았으나 이들 작업의 노출시간이 나 빈도 등이 기준에 미치지 못하는 것으로 나타났다. 하지 만 병원에서 이루어지는 업무는 대부분 비정형적인 작업이 며 동일한 작업의 반복이 아니라 환자의 상태, 입원해 있는 환자의 수에 의한 작업의 강도에 따라 작업의 형태 및 빈도 등이 좌우될 수 있다(Schibye et al., 2003; Radovanomic et al., 2004). 그렇기 때문에 법적 기준에 준하지 않더라도 간병인 업무의 대부분을 관리대상 작업으로 분류하여 체계 적인 근골격계질환 관리 및 작업관리가 요구된다고 할 수 있다. 이와 유사한 선행연구에서 조흠학(2008)은 간병인의 사고나 상해의 원인에 대한 복수응답 결과 환자체위변경 등 과 같은 과도한 동작 $(77.0 \%)$ 이 가장 많으며, 다음은 침대, 휠체어 등의 구조상 나타나는 위험요소들 $(49.7 \%)$, 간병인 1 인당 환자 수가 너무 많음 $(32.7 \%)$ 의 순으로 나타났다.

선행연구에서 병원종사 근로자에서 가장 많이 발생하는 근골격계질환은 요통으로 알려져 있으며(Jeanne MS, 1998) 병원종사자들의 근골격계질환은 환자의 이동이나 물품 운반 과 관련된 부적절한 자세 및 간호 방법과 관련이 많다고 알 려져 있다. 이러한 근골격계질환의 발생빈도는 다른 업종의 근로자들과 비교해 2 배에 이르는 것으로 나타났다(Lagerlof, E, Broberg, E, 1989).

본 연구에서도 간병인의 $78.6 \%$ 가 요통을 경험하고 있는 것으로 나타났으며 그 원인으로 생각되어 지는 환자 옮기기 와 체위변경이 각각 전체 작업 중 $36.3 \%$ 와 $18.2 \%$ 매우 높 은 비율을 차지하였고 몸통/허리 자세 분석 결과에서도 허리 를 옆으로 20도 이상 비튼 자세, 앞으로 굽힌 체 옆으로 비 튼 자세가 각각 $37.4 \%, 27.5 \%$ 로 나타나 해당 작업을 2시 간 이상 지속적으로 작업을 수행할 경우 또는 하루에 10회 이상 $25 \mathrm{~kg}$ 이상의 물체를 드는 경우 근골격계 부담이 발생 할 가능성이 높은 것으로 노동부 고시 11 개 부담작업 제 8 호 에서 설명하고 있다.

이는 조흠학(2008)의 조사연구에서 간병인이 주관적으로 느끼는 근골격계질환이 어깨(65.7\%), 등/허리(60.3\%), 손 목/손(48.7\%), 다리/발 $(47.0 \%)$ 순으로 근골격계질환을 느 끼고 있으며, 근골격계질환을 겪고 있는 응답자 중 $82.6 \%$ 가 업무연관성이 있다고 응답한 연구와 유사하게 나타났다. 또한 윤조덕과 한충현(2008)의 연구에서는 간병인의 안전
보건은 매우 취약하여 환자의 일상생활 및 거동을 도와주어 야 하는데 이 작업의 반복은 근골격계질환(척추질환, 손목질 환 등)에 쉽게 노출되어 있다고 연구 보고하였다.

우리 나라에서는 요통 원인으로 들기 작업이 추락 다음으 로 높은 것으로 조사되었다(기도형, 정민근, 1995). 이러한 이유로 들기, 내리기, 밀기, 당기기, 운반 등의 여러 형태의 인력 운반작업 중에서 들기 작업이 인간공학 분야에서 가 장 많은 연구가 되어 왔다(기도형, 2006). 1인 혹은 2 인이 수행하는 환자 운반(transfer), 위치바꾸기(repositioning) 작업은 모두 L5/S1 compressive force가 NIOSH 들기 작 업 공식의 기준으로 사용되는 $3,400 \mathrm{~N}$ 을 초과하여, 요통 등 의 근골격계질환을 유발할 위험이 높은 것으로 알려져 있다 (Marras et al., 1999).

이러한 결과로 볼 때 요양병원 간병인에 대한 작업 부담 개선에 대한 연구 및 근골격계질환 예방관리가 필요할 것으 로 판단된다.

본 연구의 제한점으로는 일부 특정 도시에 위치한 요양병 원 3곳을 중심으로 연구가 진행되어 극히 일부분의 특정 도 심지역을 대상으로 진행되었다는 점과 업무의 특성상 특정 업무를 수행함에 있어서 꼭 정해진 특정 자세가 없으므로 충분한 교육과 준비 운동으로 근골격계질환을 일으킬 수 있 는 동작을 피하거나 통증을 줄일 수 있을 것으로 생각되어 지는데 전문적인 교육을 받아온 간병인들과 교육을 받지 못 한 간병인들을 구분해서 조사하지 않은 점이 미흡한 점으로 남는다. 추후에 이루어질 연구에서는 보다 다양하고 광범위 한 지역의 간병인들을 대상으로 업무에 대한 교육을 충분히 받은 간병인과 그렇지 못한 간병인들간의 근골격계 자각증 상을 비교해 볼 필요가 있을 것이다. 따라서 근골격계질환을 예방하고 이로 인한 경제적, 인적 손실을 줄이기 위해서는 병원 작업 방법, 환경에 대한 인간공학적 개선을 실시하는 등, 충분한 교육과 적극적인 대책이 필요할 것으로 사료된다.

\section{References}

Ando, S., Ono, Y., Shimaoka, M., Hiruta, S., Hattori, Y., Hori, F. and Takeuchi, Y. Associations of self estimated workloads with musculoskeletal symtoms among hospital nurse. Occupational Environmental and Medicine, 57, 211-216, 2000.

Bejia, I., Younes, M., Janila, H. B., Kha;FA;;Ah, T., Ben Salem, K., Touzi, M., Akrout, M. and Bergaoui, N., Prevalence and factors associated to low back pain among hospital staff. Joint Bone Spine, 254-259, 2005 .

Cho, H. H., The Feature and Prevention Measures of Industrial Injury of 
Independent Contractors. Korea Occupational Safety \& Health Agency of Occupational Safety \& Health Research Institute, General field studies. 145-1487, 2008.

Hignett, S. and McAtamney, L., Rapid Entire Body Assessment: REBA, Applied Ergonomics, 31, 201-205, 2000.

Hopkins, H. L., Smith, H. D., et al. Occupational therapy. 8th ed., Philadelphia: JB Lippincdtt, Co, 1993.

Hwang, N. M., Choe, B. H., Park, H. T. and Kim, D. J., Public Caregivers' Services in Medical Centers Social Institutionalization measure. Korea Institute for Health and Social Affairs. Ministry of Gender Equality \& Famaily Research Reports. 4, 2006.

Jeanne, M. S., Encyclopedia of occupational health and safety. In: Annalee Y, Leon JW, editors. Health care: its nature and its occupational health problems. Geneva, ILO, 4, 972-978, 1998.

Kee, D. H. and Chung, M. K., Analysis of Symptoms and Causes for Low Back Injuries reported in the Pohang Region. Korean Institute of Industrial Engineers, 8(4), 145-154, 1995.

Kee, D. H., Applicability of NIOSH Lifting Equation to analysis of Workload for Patients Transferring. Journal of the Ergonomics Society of Korea, 25(2), 43-50, 2006.

Kim, K. J., City of homemaker and caregiver attitudes are required for the study on feature. Master's thesis. Chung-ang university The Graduate School of Social Development. 1998.

Knibbe, J. J. and Friele, R. D., Prevalence of back pain and characteristics of the physical workload of community nurses, Ergonomics, 39(2), 186-198, 1996.

Korean Hospital Association, 2006 List of hospitals nationwide, Seoul, 2006.

Korean Industrial Safety Association. Disaster Prevention of transport operations personnel, 1-4, 2005.

Korean Statistical Information Service, Economically Active Population by Age Group, www.nso.go.kr, 2003 2008.

Korea Occupational Safety \& Health Agency, A Statistical Characteristics of on Industrial Accidents from a Computerized Database, 2000 2007.

Lagerlof, E. and Broberg, E., Occupational injuries and diseases. In: brune, D.K., Elding, C., editors. Occupational hazard in health professions, Boca Raton, CRC Press, 1989.

Marras, W. S., Davis, K. G., Kirking, B. C. and Bertsche, P. K., A comprehensive analysis of low-back disorder risk and spinal loading during the transferring and repositioning of patients using different techniques. Ergonomics, 42(7), 904-926, 1999.

McAtamney, L. and Corlett, E. N., RULA: a survey method for the investigation of work-related upper limb disorders, Applied Ergonomics, 24(2), 1993.

Ministry of health \& welfare. Briefing the first half of job creation in the field of health and welfare. 2010. 8

National Institute for Occupational Safety and Health(NIOSH). NIOSH Health Hazard Evaluation Report, No. PB 93-188-456, 1993.

Notification of Ministry of Labor (no. 2003-24), 2003.

Oh, J. M., Several Risk Factors of Low Back Pain in General Hospital
Nurses - Based on Operating Room Nurses. Master's Theses. Catholic University Graduate School Of Public Health; Industrial health the science of nursing. 1997.

Park, H. J., Jeong, B. Y. and Kim, H. H., Study of the characteristic of indestrial accident in the hospital and clinic depends on the occupation. Journal of the Ergonomics Society of Korea spring conference, 2008.

Park, J. K. and Park, S H., Effects of Material Position on Postural Stability during Manual Material Handling Tasks, Journal of the Ergonomics Society of Korea, 23(4), 1-8, 2004.

Park, J. K., Kim, D. S. and Seo, K. B., Musculoskeletal Disorder Symptom Features and Control Strategies in Hospital Wokers, Journal of the Ergonomics Society of Korea, 27(3), 81-92, 2008.

Park, K. H. and Jeong, B. Y., Characteristics and Causes of Musculoskeletal Disorders for Employees Aged 50 Years of older, Journal of the Ergonomics Society of Korea, 28(4), 139-145, 2009.

Park, K. Y. and Song, K. A., A Study on the Degree of Burden and Depression in Family Caregivers of Patients with Stroke, Korean Sociery of Mursing Science, 26(4), 853-867, 1996.

Radovanomic, C. A. T. and Alexandere, N. M. C., Validation of an instrument for patient handling assessment. Applied Ergonomics, 34, $321-328,2004$

Schibye, B., Hansen, A. F., Hey-Kundsen, C. T., Essendrop, M., Bocher, M. and Skotte, J., Biomechanical analysis of the effect of changing patient-handling technique. Applied Ergonomics, 34, 115-203, 2003.

Scott, G. B. and Lambe, N. R., Working practices in a perchery system, using the OVAKO working posture analyzing system. Applied Ergonomics, 22(4), 281-284, 1996.

Statistics Korea (2007). Annual Report on the Cause of Death Statistisc 2006. Seoul: Sraristics Korea Press.

Yoon, J. D., Lee, S. R., Lee, H. G., Kim, Y. M., Lee, J. E., Han, C. H. and Kim, H. M., Employees working on a special form of accident insurance coverage issues and improvement. Korea Labor Institute, Ministry of Labor. 2008.

\section{Author listings}

Young-Youl You: ypnff@hanmail.net

Highest degree: Department of Rehabilitation, Graduate School of Health Sciences, Hallym University, Doctoral course

Position title: Adjunct Professor of Physical Therapy, Hallym University Areas of interest: Motion Analysis of the Elderly, Posture Analysis of nervous system diseases 
Byoung-Hee Lee: 3679@syu.ac.kr

Highest degree: Department of Physical Therapy, Sahmyook University, Doctoral graduates, Professor

Position title: Department of Physical Therapy, Sahmyook University,

Seoul

Areas of interest: Pediatric Physical Therapy, Virtual Rehabilitation, Balance and gait analysis
Date Received : 2010-08-30

Date Revised : 2011-02-11

Date Accepted : 2011-02-21 